\title{
A magnetic polarity time scale for the Early Cretaceous and Late Jurassic
}

\author{
W. Lowrie ${ }^{1}$ and J.G. Ogg ${ }^{2}$ \\ ${ }^{\prime}$ Institut für Geophysik, ETH-Hönggerberg, 8093 Zürich (Switzerland) \\ ${ }^{2}$ Scripps Institution of Oceanography, University of California at San Diego, La Jolla, CA 92093 (U.S.A.)
}

Received May 15, 1985; revised version accepted October 30, 1985

\begin{abstract}
The ages of polarity chrons in previous M-sequence magnetic polarity time scales were interpolated using basal sediment ages in suitably drilled DSDP holes. This method is subject to several sources of error, including often large paleontological age ranges. Magnetostratigraphic results have now tied the Early Cretaceous and Late Jurassic paleontological stage boundaries to the $\mathrm{M}$-sequence of magnetic polarity. The numeric ages of most of these boundaries are inadequately known and some have been determined largely by intuition. An examination of relevant data suggests that $114 \mathrm{Ma}, 136 \mathrm{Ma}$ and $146 \mathrm{Ma}$ are optimum estimates for the ages of the Aptian/Barremian, Cretaceous/Jurassic and Kimmeridgian/Oxfordian stage boundaries, respectively. Each of these boundaries has a good correlation to the M-sequence of magnetic reversals. The magnetostratigraphic tie-level ages are linearly related to the spreading distance and have been used to calculate a new magnetic polarity time scale for the Early Cretaceous and Late Jurassic. All stage boundaries in this time interval were correlated by magnetic stratigraphy to the proposed new time scale which was then used to estimate their numeric ages. These are, with the approximate relative errors of placement within the M-sequence:

$\begin{array}{ll}\text { Aptian/Barremian } & 114 \mathrm{Ma}(+0.5 \mathrm{Ma}) \\ \text { Barremian/Hauterivian } & 121 \mathrm{Ma}(-2.0,+1.5 \mathrm{Ma}) \\ \text { Hauterivian/Valanginian } & 126 \mathrm{Ma}(-0.5,+3.0 \mathrm{Ma}) \\ \text { Valanginian/Berriasian } & 131 \mathrm{Ma}(-0.5,+2.5 \mathrm{Ma}) \\ \text { Berriasian/Tithonian } & 136 \mathrm{Ma}(+1.0 \mathrm{Ma}) \\ \text { Tithonian/Kimmeridgian } & 143 \mathrm{Ma}(+0.5 \mathrm{Ma}) \\ \text { Kimmeridgian/Oxfordian } & 146 \mathrm{Ma}(+0.2 \mathrm{Ma})\end{array}$

The absolute errors of these interpolated stage boundary ages depend on the accuracy of the tie-level ages.
\end{abstract}

\section{Introduction}

Magnetostratigraphic investigations in paleontologically dated sedimentary sequences have confirmed the Late Cretaceous and Paleogene geomagnetic polarity record derived from interpretation of oceanic magnetic anomalies [1]. The paleontological ages of basal sediments in DSDP holes drilled on known anomalies agree well with the ages determined for these anomalies from the magnetostratigraphic correlations. A magnetic polarity time scale is obtained by associating the best available numeric ages with key stage boundaries which have been correlated to the polarity sequence and by interpolating the ages of intervening polarity chron boundaries between these tie-levels. For the original time scale of

Institut für Geophysik, ETH-Zürich, Contribution No. 496.
Heirtzler et al. [2] no tie-level was available beyond the oldest radiometrically dated continental lavas. The time scale of LaBrecque et al. [3] included the magnetostratigraphic correlation of the Tertiary/Cretaceous boundary in the Gubbio section [4] and an improved sequence of Late Cretaceous polarity [5]. Subsequent versions of the late Cretaceous and Cenozoic polarity time scale differ from each other in their assumptions concerning the number of acceptably well dated stage and sub-stage boundaries and the numeric ages associated with them [1,6-8].

The ages of the Late Jurassic and Early Cretaceous $\mathrm{M}$-sequence polarity chrons are less well known. Time scales have been calibrated using the paleontological ages of basal sediments in suitably placed DSDP holes. The time scales of Larson and Pitman [9] and Larson and Hilde [10] were based on the assumption that the sea-floor spreading rate 
on the Hawaiian lineations remained constant. The ages of reversal boundaries were dated by interpolating linearly between two groups of sites, near the young and old ends of the M-sequence respectively. Vogt and Einwich [11] added extra sites to the younger group and an early Valanginian tie-point at DSDP site 387 near the middle of the sequence, between M15 and M16. Their time scale was interpolated on two linear segments corresponding to visual optimum fits.

The ranges of the basal sediment paleontological ages at these DSDP tie sites are large, frequently greater than an entire stage. At sites 303 and 304 nannofossil and foraminiferal age estimates have each a two-stage range with the nannofossil ages a stage older than the foraminiferal ages. In addition, the locations of the DSDP sites relative to the anomaly sequence are sometimes imprecise, particularly for DSDP sites 100 and 105 at the old end of the sequence. As a result, the $M$-sequence magnetic polarity time scales are inadequately calibrated and predict incorrect ages for chron boundaries.

\section{Magnetostratigraphic correlation of M-sequence tie-levels}

The Aptian/Barremian, Cretaceous/Jurassic and Kimmeridgian/Oxfordian boundaries are now reasonably well correlated to the magnetic reversal pattern. The magnetostratigraphic correlations differ substantially from the associations between stage boundaries and magnetic anomalies predicted by previous $M$-sequence time scales.

The time scales of Larson and Hilde [10] and Vogt and Einwich [11] predicted a mid-Aptian age for $\mathrm{M} 0$, the youngest polarity chron of the M-sequence. M0 has been identified in Italian magnetostratigraphic sections in the Biancone limestone in the Vicentinian Alps [12] and the Maiolica limestone in Umbria [13]. Foraminiferal and nannofossil studies place the age of $\mathrm{M} 0$ as earliest Aptian, just younger than the Aptian/Barremian boundary. New results from a reevaluation of the nannofossil stratigraphy of the Umbrian Maiolica sections suggest a slightly higher correlation for this stage boundary, low within M0 (Bralower [14], and personal communication, 1985).

Larson and Hilde [10] predict the Cretaceous/ Jurassic boundary to lie near to M16, and Vogt and Einwich [11] locate it within and near to the old edge of M17. Magnetostratigraphic investigations in Umbria $[15,16]$ agree with a location near the old edge of M17. However, a different correlation of the boundary close to M18 was found in limestones from the southern Alps [17] and in DSDP sediments from the northern Atlantic [18]. Investigations of the magnetic polarity sequence in the Berriasian type section in southern France $[19,20]$ imply a Cretaceous/Jurassic boundary location older than that found in Umbria, but the stratotype section does not extend completely to the boundary. Discrepancies in the boundary correlation result in part from the use of different biostratigraphic schemes [21,22] and the lack of paleontological unity of the definition of the boundary. A reasonable case can be made for a magnetochronologic definition of the Cretaceous/ Jurassic boundary and we propose that it be associated with the old edge of chron M18 in the magnetic polarity sequence [23].

An early to middle Oxfordian age was predicted for M25 [10,11]. However, recent magnetostratigraphic results from Jurassic limestones in the Betic Cordillera of southern Spain [24] correlate the Kimmeridgian/Oxfordian boundary within M24B. This correlation is not unique and a slightly different interpretation of the data is followed here, with the boundary within M25.

In the remainder of this paper the Aptian/ Barremian boundary is placed at the old edge of M0, the Cretaceous/Jurassic boundary at the old edge of M18 and the Kimmeridgian/Oxfordian boundary within M25. These correlations form the basis for a new magnetic polarity time scale for the $\mathrm{M}$-sequence of oceanic magnetic anomalies.

\section{Revision of the Late Jurassic and Early Creta- ceous polarity time scale}

Any attempt to form a magnetic polarity time scale for Late Jurassic and Early Cretaceous time is handicapped by the scarcity of reliable numeric dates for these stages. Most age dates are not obtained directly at a stage boundary but for samples that are allocated biostratigraphically to a stage. Thus the problems of reliability of radiometric age determination are compounded by sometimes uncertain biostratigraphic correlations. Consequently, age dates for rocks from neighbouring 
stages often overlap and the age of the boundary must be interpolated.

Harland et al. [25] decided that not any of the stage boundaries between the early Cretaceous Albian/Aptian and the middle Triassic Ladinian/ Anisian boundaries were sufficiently well dated to serve as tie-points in preparing a revised geologic time scale. Accordingly, they estimated the ages of all Early Cretaceous, Jurassic and Late Triassic stage boundaries by assuming equal duration of each stage.

The criteria applied by Harland et al. [25] for acceptability of a tie-level were based on parabolically shaped chronograms as used in the dating of polarity sequences in young lavas [26]. The Albian/Aptian boundary was adopted as a tie-level with a chronogram age of $113 \mathrm{Ma}$. However, this critical tie-level is not defined entirely satisfactorily. The chronogram minimum, although pronounced, is far from zero, indicating that many age estimates for the adjacent stages overlap. Hallam et al. [27] placed this boundary at $107 \mathrm{Ma}$, following Kennedy and Odin [28] who considered it to be not younger than $106 \mathrm{Ma}$ or older than $108 \mathrm{Ma}$.

The Albian/Aptian boundary falls within the Cretaceous magnetic quiet interval [13] in which magnetic reversals are absent or unconfirmed and cannot be used as a tie-level for calibrating the M-sequence. However, the Aptian/Barremian boundary is well correlated to the $\mathrm{M}$-sequence reversal history. Kennedy and Odin [28] estimated its age to be around $112( \pm 2) \mathrm{Ma}$. Hallam et al. [27] suggest that $114 \mathrm{Ma}$ be used until there are more reliable dates close to the boundary. This compares with an age of $119 \mathrm{Ma}$ derived by assuming equal stage durations [25].

The assumption of equal stage duration yields an interpolated age of $144 \mathrm{Ma}$ for the Cretaceous/ Jurassic boundary, which is much older than most estimates and falls outside the relevant data (Fig. 1). Armstrong [29] deduced a comparable age (142 Ma) but it depends largely on intrusives from western North America which may be rather imprecisely dated biostratigraphically [27]. Harland et al. [25] computed a chronogram age of $135 \mathrm{Ma}$ for the Berriasian/Tithonian boundary. This data point was discarded because the associated error range ( $5 \mathrm{Ma}$ ) was equal to but not less than their rather arbitrary limit for acceptability. With only

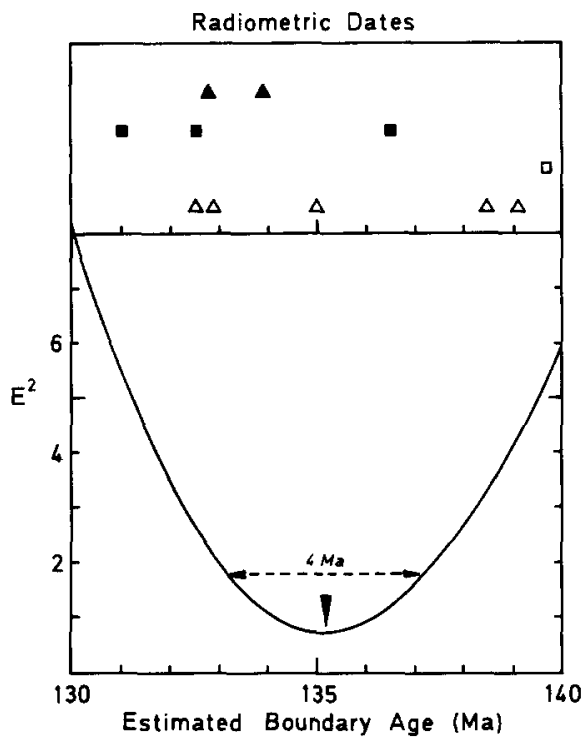

Fig. 1. Chronogram of radiometric dates relevant to definition of the Cretaceous/Jurassic boundary (from [25, Table 3.1]). Solid symbols refer to rocks of Early Cretaceous age (upper two lines), open symbols to rocks of Early Jurassic age (lower two lines). Triangles are glauconite dates, squares are other dates. The parameter $E^{2}[25,26]$ is minimum at the best estimate of the boundary age; half the width of the parabola where $E^{2}$ exceeds its minimum value by 1.0 is taken as an estimate of the age error.

slight loosening of this criterion the boundary between Berriasian and Tithonian could have been used as an additional tie-level for their time scale, as we do in this paper. Harland et al. [25] would then have had to interpolate on two segments because the $135 \mathrm{Ma}$ age does not lie on the straight line joining the two tie-levels which they used for linear interpolation.

The relevant Early Cretaceous and Late Jurassic age dates compiled and corrected by Harland et al. [25] are certainly few but they give a chronogram with a well-defined minimum (Fig. 1). It gives an age of $135 \mathrm{Ma}$ for the Cretaceous/Jurassic boundary. The error estimated from the half-width is $\pm 2 \mathrm{Ma}$. An age of $135 \mathrm{Ma}$ (with a broader error intuitively estimated as $\pm 5 \mathrm{Ma}$ ) is judged by Hallam et al. [27] to be the most satisfactory present estimate, with possible preference for a slightly older age. If the glauconite data in Fig. 1 are evaluated alone, they give a boundary age of $133 \mathrm{Ma}$. The non-glauconite data are too sparse to be used alone but suggest a somewhat higher age of 136-140 Ma. Although glauconites give radiometric age dates that are often regarded as too 
low, they can give correct ages when properly selected [28]. Glauconite dates constitute an important body of radiometric age data which can not simply be ignored, although extra weight might be given to high temperature data where available. As a compromise with the above we associate an age of $136( \pm 2) \mathrm{Ma}$ with the Jurassic/Cretaceous boundary.

Van Hinte [30] recognized the approximate time equivalence of biozones and constructed a Jurassic time scale by allocating equal length of approximately $1 \mathrm{Ma}$ to each ammonite zone. Using a similar approach Hallam et al. [27] subdivided the Jurassic into 79 equal chrons corresponding approximately to the number (74) of Jurassic ammonite subzones. The duration of each Jurassic stage was estimated from the number of chrons it contains. By this means an age of $146 \mathrm{Ma}$ was inferred for the Kimmeridgian/Oxfordian boundary. A much older age of $156 \mathrm{Ma}$ was inferred by the equal stage duration assumption [25], in agreement with an age estimated from whole-rock $\mathrm{K} / \mathrm{Ar}$ dates [29]. The construction of a time scale by the equal chron method inherently implies relatively constant ammonite evolution rates. This assumption breaks down in the Cretaceous but appears to hold well for the Jurassic [27]. It is more plausible than assuming equal duration of biostratigraphic stages.

The Hallam et al. [27] time scale gives ages of $114 \mathrm{Ma}$ for the Aptian/Barremian and $146 \mathrm{Ma}$ for the Kimmeridgian/Oxfordian boundaries. We use our above estimate of $136 \mathrm{Ma}$ for the Jurassic/Cretaceous boundary. The correlations of the tie-level stage boundaries to the magnetic polarity sequence and their associated numerical ages are then:

(1) Aptian/Barremian (age $114 \mathrm{Ma}$ ), near old edge of $\mathrm{MO}$;

(2) Berriasian/Tithonian (age $136 \mathrm{Ma}$ ), near old edge of M18;

(3) Kimmeridgian/Oxfordian (age $146 \mathrm{Ma}$ ), within M25.

The ages of the tie-level stage boundaries were plotted against distance along the Hawaiian lineations to the corresponding anomalies. The nearly straight-line fit (Fig. 2) lends support to the assumption of constant spreading rate on the Hawai-

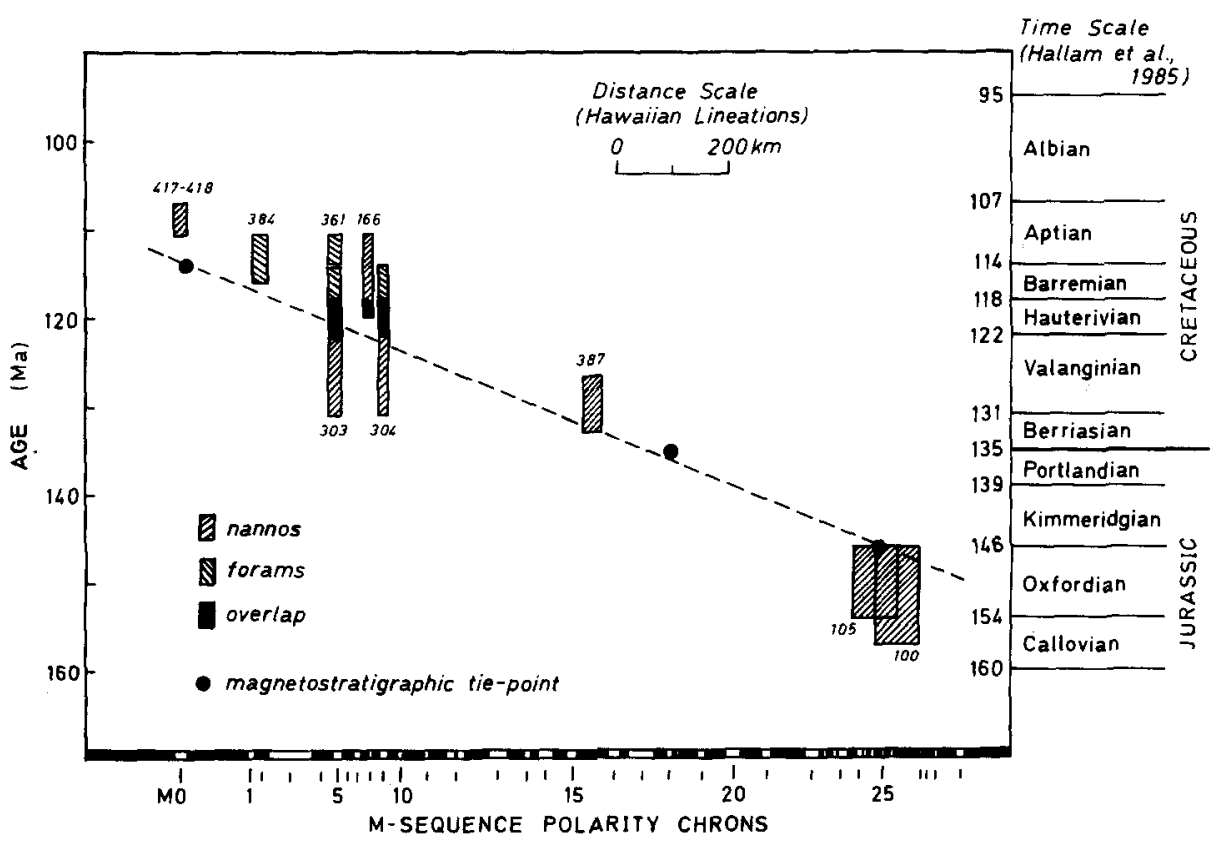

Fig. 2. Biostratigraphic ages of basal sediment at DSDP sites drilled on M-sequence anomalies, and magnetostratigraphic correlations of key stage boundaries. The polarity chron lengths are proportional to distance along the Hawaiian lineations assuming a constant rate of sea-floor spreading [10]. 
ian lineations during formation of the M-sequence magnetic anomalies $[9,10]$ and obviates the need for a change of spreading rate in the Valanginian [11].

The magnetostratigraphic correlations do not agree well with the ages determined for the basal sediments in the DSDP holes used to calibrate the M-sequence (Fig. 2). The position of the straight line implies that the quoted ages of the DSDP holes are mostly too young, by approximately half a stage or more. The ages determined for the older sites 100 and 105 are about a stage too old. This

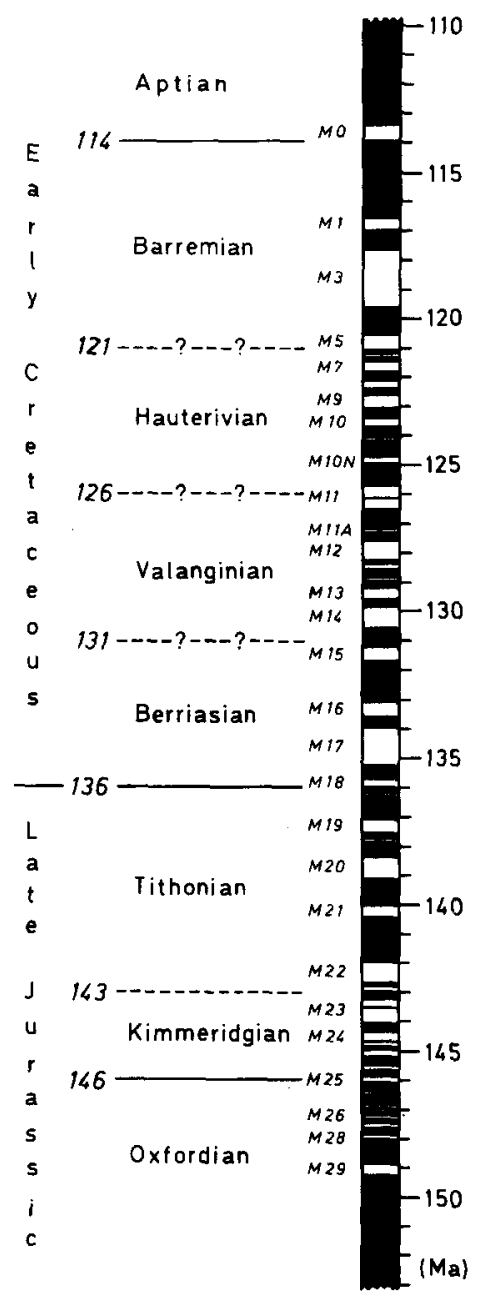

Fig. 3. Revised magnetic polarity time scale for Early Cretaceous and Late Jurassic time. Solid lines represent magnetostratigraphically correlated stage boundaries, the radiometric ages of which were used to calibrate the reversal time scale. The ages of the discontinuous stage boundaries have been calculated from their magnetostratigraphic correlations to this time scale.
TABLE 1

Revised ages for Early Cretaceous and Late Jurassic intervals of reversed magnetic polarity

\begin{tabular}{|c|c|c|}
\hline Chrons & Subchrons & $\begin{array}{l}\text { Interval } \\
\text { boundaries } \\
\text { (Ma) }\end{array}$ \\
\hline M0 & & $113.38-114.00$ \\
\hline M1 & & $116.62-117.00$ \\
\hline M3 & & $117.66-119.63$ \\
\hline M5 & & $120.56-121.07$ \\
\hline M6 & & $121.21-121.31$ \\
\hline M7 & & $121.47-121.85$ \\
\hline M8 & & $122.15-122.38$ \\
\hline M9 & & $122.65-123.09$ \\
\hline \multirow[t]{3}{*}{ M10 } & & $123.41-123.73$ \\
\hline & $\mathrm{M} 10 \mathrm{Nn}-1$ & $124.06-124.10$ \\
\hline & $\mathrm{M} 10 \mathrm{Nn}-2$ & $124.42-124.43$ \\
\hline M10N & & $124.72-124.97$ \\
\hline M11 & & $125.72-126.15$ \\
\hline M11 & & $126.19-126.54$ \\
\hline M11A & & $127.22-127.32$ \\
\hline M12.1 & & $127.60-128.30$ \\
\hline M12.2 & & $128.38-128.56$ \\
\hline M12A & & $128.87-128.97$ \\
\hline M13 & & $129.20-129.60$ \\
\hline M14 & & $129.85-130.62$ \\
\hline M15 & & $131.22-131.71$ \\
\hline M16 & & $133.08-133.63$ \\
\hline M17 & & $133.98-135.25$ \\
\hline \multirow[t]{2}{*}{ M18 } & & $135.73-136.00$ \\
\hline & M19n-1 & $136.20-136.27$ \\
\hline \multirow[t]{2}{*}{ M19 } & & $137.13-137.53$ \\
\hline & M20n-1 & $137.79-137.84$ \\
\hline M20 & & $138.40-139.13$ \\
\hline \multirow[t]{3}{*}{ M21 } & & $140.05-140.45$ \\
\hline & M22n-1 & $141.78-141.82$ \\
\hline & $M 22 n-2$ & $141.87-141.92$ \\
\hline M22 & & $141.98-142.69$ \\
\hline M22A & & $142.81-142.96$ \\
\hline M23 & & $143.27-143.51$ \\
\hline M23 & & $143.53-144.06$ \\
\hline M24 & & $144.35-144.66$ \\
\hline M24 & & $144.69-144.86$ \\
\hline M24A & & $144.97-145.20$ \\
\hline M24B & & $145.50-145.64$ \\
\hline \multirow[t]{3}{*}{ M25 } & & $145.88-146.10$ \\
\hline & M25An-1 & $146.23-146.30$ \\
\hline & M25An-2 & $146.38-146.45$ \\
\hline \multirow[t]{4}{*}{ M25A } & & $146.57-146.66$ \\
\hline & M26n-1 & $146.74-146.81$ \\
\hline & M26n-2 & $146.86-146.94$ \\
\hline & M26n-3 & $147.01-147.05$ \\
\hline M26 & & $147.21-147.34$ \\
\hline M27 & & $147.52-147.65$ \\
\hline M28 & & $147.90-148.07$ \\
\hline M29 & & $148.87-149.32$ \\
\hline
\end{tabular}


has important consequences for the accuracy of previous M-sequence time scales which rely heavily on these sites for calibration [9-11]. A similar comparison made tor Late Cretaceous Cenozoic DSDP sites [1] showed good agreement with magnetostratigraphic results. The poor agreement for the early Cretaceous and late Jurassic warrants a new examination of the dating of the $\mathrm{M}$-sequence oceanic magnetic anomalies.

Linear interpolation was used to obtain numeric ages for the chron boundaries between $\mathrm{M} 0$ and M25. The polarity sequence for this interval is that obtained by Larson and Hilde [10], extended by additional oceanic magnetic reversals M25-M29 identified in the Pacific Ocean [31]. Following Harland et al. [25] the anomaly M25-M29 ages were calculated by linear extrapolation from the rest of the M-sequence, although there is no certainty that sea-floor spreading remained constant during their formation. The Middle and Late Oxfordian ages of anomalies M25-M29 agree with magnetostratigraphic results from sections dated with ammonites in north-central Spain [32].

The revised magnetic polarity time scale for the entire Late Jurassic and Early Cretaceous M-sequence of magnetic anomalies is given in Fig. 3 and Table 1. As in other time scales [9-11] the chron ages are given to two decimal places. The boundaries of magnetized oceanic crustal blocks are located on the Hawaiian lineations within about $1-2 \mathrm{~km}$. Using a spreading rate of $3.3 \mathrm{~cm} / \mathrm{yr}$ this gives a precision of $0.03-0.06 \mathrm{Ma}$ for the chron boundary ages within the relative polarity sequence [10]. This does not imply a corresponding absolute accuracy, which depends on the calibration of the tie-points and is around 2-5 Ma.

\section{Stage boundary age estimates from magneto- stratigraphic correlations}

The ages of Late Jurassic and Early Cretaceous stage boundaries are poorly determined by existing radiometric data and the values quoted are often largely intuitive. Magnetostratigraphic correlations of these stage boundaries to the new time scale should provide improved estimates of the numeric ages of the boundaries.

The Barremian/Hauterivian boundary was not correlated to the oceanic magnetic polarity sequence in the Italian Cismon section [12] as it could not be recognized with nannofossils. Its expected position was in a part of the section where the magnetic stratigraphy was ambiguous. This boundary also was not located precisely in the Gorgo a Cerbara section. Although the magnetic stratigraphy here correlates quite well with the M-sequence [13], the nannofossils are mostly poorly preserved and Bralower ([14], and personal communication, 1985) can at present only locate the boundary between M3 and M8. Magnetostratigraphic zonations at DSDP sites 534 and 603 do not clear up this problem because they have no obvious match to the $\mathrm{M}$-sequence. By involving several additional constraints Ogg [33] has proposed a correlation with M5 or M6. Comparison with the new time scale (Fig. 3) suggests an age of around 119-122 Ma for this boundary. The optimum estimate may be $121 \mathrm{Ma}$, corresponding to the M5/M6 correlation.

The Hauterivian/Valanginian boundary is found in the Cismon section at a level where the magnetostratigraphy can not be correlated with the oceanic polarity sequence. In the Fonte del Giordano section [17] it lies in a stratigraphic gap above magnetozone M14n and in the Bosso section [15] it falls within M13. Micarelli et al. [34] assigned the end of the Valanginian in these sections to the extinction of calpionellids. However, according to Remane [35] the calpionellids disappear shortly after the beginning of the Late Valanginian. The Hauterivian/Valanginian boundary must then have a younger correlation than with M13. If the Late and Early Valanginian were of roughly comparable lengths, M12 and M11 may be included in the Valanginian. Although a slightly younger correlation with the $\mathrm{M}$-sequence may be found by further magnetostratigraphic study, at present the optimum location for the Hauterivian/ Valanginian boundary is around M11, which gives it an estimated age of about $126 \mathrm{Ma}$.

The Valanginian/Berriasian boundary as defined by the biostratigraphy of Micarelli et al. [34] was located within M16 in the Fonte del Giordano section and within M16n in the Bosso section. Again a small discrepancy in the placement of this boundary arises from the zonal scheme used. If the later calpionellid zonation scheme of Remane [35] is used, the Valanginian/Berriasian boundary would fall in or just younger than M15. This revision is consistent with the results from the 
Berriasian stratotype section [20], where the boundary was in a covered interval above a negative magnetozone which may correspond to M15. In view of these observations we place this boundary just younger than M15 which gives it an estimated age of $131 \mathrm{Ma}$.

The Tithonian/Kimmeridgian boundary was correlated in Spanish sections [15] with the young edge of M23. Although this correlation may be associated with a hiatus it agrees favourably with a correlation near M22 found in the magnetostratigraphy of DSDP site 534 [19]. Comparison with the magnetic polarity time scale suggests an age of 143 $\mathrm{Ma}$ for this boundary, reasonably close to the 141 Ma age proposed by Van Hinte [30] on the assumption of equal biozone durations.

\section{Discussion and conclusions}

Kent and Gradstein [36] have independently approached the problem of dating the Early Cretaceous and Jurassic stage boundaries by the same method. They rely on only two calibration tie-levels at the Aptian/Barremian and Kimmeridgian/ Oxfordian boundaries between which they interpolate linearly assuming a constant sea-floor spreading rate. Fig. 2 implies that this assumption is justified. However, they attach to their tie-levels the ages (119 Ma, $156 \mathrm{Ma}$ ) interpolated by Harland et al. which are respectively $5 \mathrm{Ma}$ and $10 \mathrm{Ma}$ older than the ages used in the present paper. Consequently, they deduce correspondingly older ages for intervening stage boundaries. Their magnetostratigraphic correlations of stage boundaries in the Early Cretacous come from the Umbrian results $[13,15]$ which use an unorthodox calpionellid biostratigraphy [34]. We have modified the correlations as far as possible to conform to the accepted calpionellid scheme [35] and have also incorporated recent DSDP results.

Clearly, estimates of stage boundary ages must be taken with caution. As yet the correlations involved have been described for too few sections and in some cases have not been directly observed but are largely inferred. Correlation problems are enhanced when different paleontological dating schemes (nannofossils, calpionellids, ammonites, dinoflagellates, etc.) are involved that have not yet been adequately tied to each other. In some sections (e.g. Cismon, Berrias, certain DSDP holes) the magnetostratigraphy can not be tied uniquely with the polarity sequence derived from oceanic magnetic lineations. It will take considerable effort and time to overcome the obstacles but the combination of biostratigraphy and magnetostratigraphy provides a means of clearing up discrepancies between different dating schemes. The absolute ages of stage boundaries can be estimated as here by correlation to the dated M-sequence of magnetic polarity. The combination of magneto- and biostratigraphic correlations have potential of providing a time scale with much finer resolution. This would be of great use in timing sedimentary rate processes such as sedimentation and diagenesis.

For example, Lowrie and Alvarez [37] noted that the Hauterivian had an unusually large thickness in the Umbrian Maiolica limestone and suggested that this might result from the Hauterivian lasting much longer than usually assumed. The new assessments of the non-standard calpionellid zonations of the Italian sections done for this paper are necessarily imprecise and a new biostratigraphic study is warranted. However, our reevaluation moves the estimated ages of the start and end of the Hauterivian closer together. This suggests that its thickness in the Umbrian Maiolica limestone is due to high sedimentation rate. This was probably due to high carbonate production which diluted the detrital fraction to such an extent that the remanent magnetization is largely unmeasurable with the precision needed for a paleomagnetic study [22,37].

The length of time represented in the new time scale by polarity chrons M0 to M25 is $32 \mathrm{Ma}$. By comparison Larson and Hilde [10] estimated this time interval at $44 \mathrm{Ma}$. Consequently, M-sequence spreading rates must have been $35-40 \%$ faster than earlier interpreted.

\section{Ackowledgements}

We thank F. Meller, D.V. Kent, H. Thierstein and an anonymous reviewer for helpful criticisms of the manuscript.

\section{References}

$1 \mathrm{~W}$. Lowrie and W. Alvarez, 100 million years of geomagnetic polarity history, Geology 9, 392-397, 1981.

2 J.R. Heirtzler, G.O. Dickson, E.M. Herron, W.C. Pitman III and X. Le Pichon, Marine magnetic anomalies, geomag- 
netic field reversals and motion of the ocean floor and continents, J. Geophy. Res. 73, 2119-2136, 1968.

3 J.L. LaBrecque, D.V. Kent and S.C. Cande, Revised magnetic polarity time scale for Late Cretaceous and Cenozoic time, Geology 5, 330-335, 1977.

4 W. Alvarez, M.A. Arthur, A.G. Fischer, W. Lowrie, G. Napoleone, I. Premoli Silva and W. Roggenthen, Late Cretaceous-Paleocene geomagnetic reversal time scale: type section in the pelagic limestone sequence at Gubbio, Italy, Geol. Soc. Am. Bull. 88, 383-389, 1977.

5 S.C. Cande and Y. Kristoffersen, Late Cretaceous magnetic anomalies in the North Atlantic, Earth Planet. Sci. Lett. 35, 215-224, 1977.

6 G. Ness, S. Levi and R. Couch, Marine magnetic anomaly timescales for the Cenozoic and Late Cretaceous: a précis, critique and synthesis, Rev. Geophys. Space Phys. 18, 753-770, 1980.

7 A.V. Cox, Magnetostratigraphic time scale, in: W.B. Harland, A.V. Cox, P.G. Llewellyn, C.A.G. Pickton, A.G. Smith and R. Walters, A Geologic Time Scale, pp. 63-84, Cambridge University Press, Cambridge, 1982.

8 W.A. Berggren, D.V. Kent, J.J. Flynn and J.A. Van Couvering, Cenozoic Geochronology, in: Geochronology and the Geological Record, N.J. Snelling, ed., Geol. Soc. London Spec. Pap., 1985.

9 R.L. Larson and W.C. Pitman III, World-wide correlation of Mesozoic magnetic anomalies, and its implications, Geol. Soc. Am. Bull. 83, 3645-3662, 1972.

10 R.L. Larson and T.W.C. Hilde, A revised time scale of magnetic reversals for the Early Cretaceous and Late Jurassic, J. Geophy. Res. 80, 2586-2594, 1975.

11 P.R. Vogt and A.M. Einwich, Magnetic anomalies and sea-floor spreading in the western North Atlantic, and a revised calibration of the Keathley $(M)$ geomagnetic reversal chronology, in: Initial Reports of the Deep Sea Drilling Project 43, pp. 857-876, U.S. Government Printing Office, Washington, D.C., 1979.

12 J.E.T. Channell, W. Lowrie and F. Medizza, Middle and Early Cretaceous magnetic stratigraphy from the Cismon section, northern Italy, Earth Planet. Sci. Lett. 42, 153-166, 1979.

13 W. Lowrie, W. Alvarez, I. Premoli Silva and S. Monechi, Lower Cretaceous magnetic stratigraphy in Umbrian pelagic carbonate rocks, Geophys. J.R. Astron. Soc. 60, 263-281, 1980.

14 T.J. Bralower, Biostratigraphic correlation of the Lower Cretaceous M-sequence in the Maiolica limestone, Italy, EOS 65, 865, 1984.

15 W. Lowrie and J.E.T. Channell, Magnetostratigraphy of the Jurassic-Cretaceous boundary in the Maiolica limestone (Umbria, Italy), Geology 12, 44-47, 1984.

$16 \mathrm{~S}$. Cirilli, P. Marton and L. Vigliotti, Implications of a combined biostratigraphic and palaeomagnetic study of the Umbrian Maiolica formation, Earth Planet. Sci. Lett. 69, 203-214, 1984.

17 J.G. Ogg, Sedimentology and paleomagnetism of Jurassic pelagic limestones ("Ammonitico Rosso" facies), 203 pp., $\mathrm{Ph}$. D. Thesis, University of California, San Diego, Calif., 1981.
18 J.G. Ogg, Late Jurassic-Early Cretaceous magnetostratigraphy, DSDP site 534, Western North Atlantic, in: Initial Reports of the Deep Sea Drilling Project 76, pp. 685-696, U.S. Government Printing Office, Washington, D.C., 1983.

19 B. Galbrun, Magnétostratigraphie de la limite JurassiqueCrétacé. Proposition d'une échelle de polarité à partir du stratotype du Berriasien (Berrias, Ardèche, France) et de la Sierra de Lugar (Province de Murcie, Espagne), 95 pp., Thèse 3ème Cycle, Université de Paris, 1984.

20 B. Galbrun and L. Rasplus, Magnétostratigraphie du stratotype du Berriasien. Premiers resultats, C.R. Acad. Sci. Paris 198, 219-220, 1984.

21 J.G. Ogg, Magnetostratigraphy of the Jurassic-Cretaceous boundary in the Maiolica limestone (Umbria, Italy): comment, Geology 12, 701, 1984.

22 W. Lowrie and J.E.T. Channell, Magnetostratigraphy of the Jurassic-Cretaceous boundary in the Maiolica limestone (Umbria, Italy): reply, Geology 12, 702, 1984.

23 J.G. Ogg and W. Lowrie, Magnetostratigraphy of the Jurassic-Cretaceous boundary, Geology, in press, 1985.

24 J.G. Ogg, M.B. Steiner, F. Oloriz and J.M. Tavera, Jurassic magnetostratigraphy, 1. Kimmeridgian-Tithonian of Sierra Gorda and Carcabuey, Southern Spain, Earth Plan. Sci. Lett. 71, 147-162, 1984.

25 W.B. Harland, A.V. Cox, P.G. Llewellyn, C.A.G. Pickton, A.G. Smith and R. Walters, A Geologic Time Scale, 131 pp., Cambridge University Press, Cambridge, 1982.

26 A.V. Cox and G.B. Dalrymple, Statistical analysis of geomagnetic reversal data and the precision of potassium-argon dating, J. Geophys. Res. 72, 2603-2614, 1967.

27 A. Hallam, J.M. Hancock, J.L. LaBrecque, W. Lowrie and J.E.T. Channell, Jurassic and Cretaceous geochronology and Jurassic to Palaeogene magnetostratigraphy, in: Geochronology and the Geological Record, N.J. Snelling, ed., Geol. Soc. London Spec. Pap., 1985.

28 W.J. Kennedy and G.S. Odin, The Jurassic and Cretaceous time scale in 1981, in: Numerical Dating in Stratigraphy, G.S. Odin, ed., pp. 557-592, (John Wiley and Sons, Chichester, 1982).

29 R.L. Armstrong, Pre-Cenozoic Phanerozoic time scale-Computer file of critical dates and consequences of new and in-progress decay-constant revisions, in: Contributions to the Geological Time Scale, G. Cohee, M. Glaessner and H. Hedberg, eds., pp. 73-91, American Association of Petroleum Geologists, Tulsa, Okla., 1978.

30 J.E. Van Hinte, A Jurassic time scale, Bull. Am. Assoc. Pet. Geol. 60, 489-497, 1976.

31 S.C. Cande, R.L. Larson and J.L. LaBrecque, Magnetic lineations in the Pacific Jurassic quiet zone, Earth Planet. Sci. Lett. 41, 434-441, 1978.

32 M.R. Steiner, J.G. Ogg, G. Melendez and L. Sequeiros, Jurassic magnetostratigraphy, 2. Middle-Late Oxfordian of Aguilon, Iberian Cordillera, Northern Spain, Earth Planet. Sci. Lett. 76, 151-166, 1985.

33 J.G. Ogg, Early Cretaceous magnetostratigraphy of sediments in the Western Central Atlantic, DSDP sites 603 and 534, in: Initial Reports of the Deep Sea Drilling Project 93, in press, U.S. Government Printing Office, Washington, D.C., 1985. 
34 A. Micarelli, M. Potetti and M. Chiochine, Ricerche microbiostratigrafiche sulla Maiolica delle regione umbromarchigiano, Stud. Geol. Camerti 3, 57-86, 1977.

35 J. Remane, Calpionellids, in: Introduction to Marine Micropaleontology, B.U. Haq and A. Boersma, eds., pp. 161-170, Elsevier, New York, N.Y., 1978.
36 D.V. Kent and F.M. Gradstein, A Cretaceous and Jurassic geochronology, Geol. Soc. Am. Bull., in press, 1985.

37 W. Lowrie and W. Alvarez, Lower Cretaceous magnetic stratigraphy in Umbrian pelagic limestone sections, Earth Planet. Sci. Lett. 71, 315-328, 1984. 